\title{
Pertumbuhan Sawi yang Berasosiasi dengan Bakteri Synechococcus sp. pada Berbagai Kondisi Media Salinitas
}

\section{Growing Sawi Associated with Bacteria Synechococcus sp. on Various Media Salinity Conditions}

\author{
Asmuni $^{1}$, Sholeh Avivi ${ }^{1 *}$, Sugeng Winarso ${ }^{1}$ \\ ${ }^{1}$ Program Studi Agroteknologi, Fakultas pertanian, Universitas Jember \\ Jln. Kalimantan 37 Kampus Tegal Boto, Jember 68121 \\ e-mail: savivi.faperta@unej.ac.id
}

Diterima 6 Januari 2017/Disetujui 21 Maret 2017

\begin{abstract}
The Mustard Greens is one type of vegetable that has many benefits such as to prevent cancer, hypertension, heart disease, helps the health of the digestive system, and prevent pregnant women from anemia. Mustard/green plants in general can live in lowland and highland, but better planting in the highlands. The research that evaluated about the resistenceof mustard green in salin law is not many. The purpose of this study was to evaluate the response of mustard greens that have been associated with bacteria Synechococcus sp to various salinity conditions. This study was conducted from November 2016 to January 2017 in the village of the District Bendoarum Wonosari regency. The planting materials used the mustard green, photosynthetic bacteria cultures (Synechococus sp), water, soil, sand, salt, $\mathrm{NaCl}$, fertilizers (urea, SP-36 and KCl). This study uses a randomized block design (RAK) with four replications. Salinity treatments given by the addition concentration of salt ( $\mathrm{NaCl})$, control (0 ppm), $2500 \mathrm{ppm}, 5000 \mathrm{ppm}, 7500 \mathrm{ppm}$ and 10,000 ppm. The response to the treatment plant is based on a variable number of leaves, the amount of chlorophyll, root length, root volume, fresh weight and dry weight. The data were analyzed using ANOVA test and Duncan's Multiple Range (DMRT) with statistical significance level of 5\%. Mustard plant responses to extra salt showed significantly different results in all growth parameters including number of leaves, the amount of chlorophyll, root length, root volume, fresh weight and dry weight. The response of plants to the scenes of salt on both bacteria Synechococcus sp given or not given showed declining results and significantly different on parameters root length, fresh weight and dry weight. Provision of Synechococcus sp bacteria in plant grown in saline soil no real effect on plant growth parameters.
\end{abstract}

Keywords: Salinity, Mustard Greens, Synechococcus sp, plant growth

\section{ABSTRAK}

Sawi hijau merupakan salah satu jenis sayur yang di konsumsi oleh masyarakat Indonesia yang memiliki banyak manfaat diantaranya untuk mencegah kanker, hipertensi, penyakit jantung, membantu kesehatan sistem pencernaan, mencegah dan mengobati penyakit pellagra, serta menghindarkan ibu hamil dari anemia. Tanaman sawi pada umumnya dapat hidup di dataran rendah maupun dataran tinggi, akan tetapi lebih baik penanamannya dilakukan di dataran tinggi. Penelitian tentang resistensi sawi di media salin belum banyak dilakukan. Tujuan dari penelitian ini adalah untuk mengetahui respon tanaman sawi hijau yang telah berasosiasi dengan bakteri Synechococcus spterhadap berbagai kondisi salinitas. Penelitian ini dilakukan mulai bulan November 2016 sampai Januari 2017 di Desa Bendoarum Kecamatan Wonosari Kabupaten Bondowoso. Adapun bahan tanam yang digunakan adalah sawi, biakan bakteri fotosintetik (Synechococus sp), air, tanah, pasir, garam NaCl, pupuk (urea, SP-36 dan KCl). Penelitian ini menggunakan Rancangan Acak Kelompok (RAK) dengan 4 kali ulangan. Perlakuan salinitas diberikan berdasarkan penambahan konsentrasi garam ( $\mathrm{NaCl}$ yaitu kontrol (0 ppm), 2500 ppm, 5000 ppm, 7500 ppm, dan 10.000 ppm. Respon ta tanaman terhadap perlakuan didasarkan pada variabel jumlah daun, jumlah klorofil, panjang akar, volume akar, berat basah, dan berat kering. Data tersebut dianalisis menggunakan uji Anova dan Jarak Berganda Duncan (DMRT) dengan signifikansi pada taraf 5\%. Respon tanaman sawi terhadap penambahan garam menunjukkan hasil yang berbeda nyata pada semua parameter pertumbuhan yang meliputi jumlah daun, jumlah klorofil, panjang akar, volume akar, berat basah, dan berat kering. Respon tanaman yang tercekam garam baik yang diberikan bakteri Synechococcus sp atau yang tidak diberikan menunjukkan hasil menurun dan berbeda nyata pada parameter panjang akar, berat basah, dan berat kering. Pemberian bakteri Synechococcus sp pada tanaman yang ditanam dilahan salin tidak berpengaruh nyata pada parameter pertumbuhan tanaman, tapi cenderung meningkatkan berat basah tanaman, berat kering tanaman, dan panjang akar tanaman.

Kata kunci : Salinitas, Sawi Hijau, Synechococcus sp, pertumbuhan tanaman 


\section{PENDAHULUAN}

Salah satu tanaman sayuran yang dapat dibudidayakan di Indonesia adalah tanaman sawi. Tanaman sawi merupakan tanaman asli daerah pesisir sungai sekitar mediterian kemudian tersebar kedaerah tropis. Sawi dapat tumbuh baik di tempat yang berhawa panas maupun berhawa dingin. Sehingga dapat di usahakan di daerah dataran tinggi maupun di dataran rendah. Produksi sawi dari tahun ke tahun mengalami penurunan. Hal ini dapat dilihat dari data BPS Gorontalo (2012), bahwa produksi sawi pada tahun 2007 sebesar 220 ton/ha, sedangkan pada tahun 2011 produksi sebesar 83 ton/ha (Haryanto, dkk., 2000).

Salah satu cara untuk meningkatakan produksi tanaman sawi di Indonesia adalah perluasan areal penanaman sawi. Tetapi perluasan areal tanaman sawi mengalami kendala dimana lahan dengan produktifitas tiggi digunakan untuk tanaman lain yang dianggap lebih penting, untuk areal industri dan perumahan.

Lahan salin pantai adalah lahan pasang surut yang terkena pengaruh air laut atau payau yang tanahnya dapat dimasukkan kategori lahan potensial, lahan sulfat masam atau gambut. Lahan salin mendapatkan intrusi air laut lebih dari 3 bulan dalam setahun dan kandungan $\mathrm{Na}$ dalam larutan tanah antara 8-15\% (Noor, 1996). Istilah salin digunakan untuk menggambarkan tanah yang kaya kadar garamnya di dalam larutan tanah. Luas total lahan salin di Indonesia adalah 60,08 juta Hektar, yang terdiri dari lahan rawa dengan luas mencapai 39,98 juta Hektar dan lahan pasang surut seluas 20,1 juta Hektar. Berdasarkan luas total lahan salin tersebut diketahui bahwa lahan yang potensial untuk program pertanian adalah seluas 9,5 juta Hektar. Sedangkan lahan potensial tersebut yang baru di manfaatkan seluas 729,9 ribu Hektar (Alihamsyah, 2004).

Tanah salin di dunia meliputi "salt marshes" di zona temperate, daerah pasang surut (mangrove swamps), di daerah subtropik dan tropic. Ditaksir antara 400-900 juta hektar lahan di dunia mempunyai problem salinitas. tanah salin sangat banyak terdapat di daerah yang curah hujannya tidak mencukupi untuk pencucian ( Leaching). Problem salinitas terjadi pada daerah non irigasi sebagai akibat dari evaporasi dan transpirasi dari air bumi yang berkadar garam tinggi atau akibat dari imput garam dari curah hujan (Didy Sopandie, 1998).

Pada kondisi salin, pertumbuhan dan perkembangan tanaman terhambat karena akumulasi berlebihan $\mathrm{Na}$ dan $\mathrm{Cl}$ dalam sitoplasma, menyebabkan perubahan metabolisme di dalam sel. Aktivitas enzim terhambat oleh garam. Kondisi tersebut juga mengakibatkan dehidrasi parsial sel dan hilangnya turgor sel karena berkurangnya potensial air di dalam sel (Yuniati, 2004). Stomata berperan penting sebagai alat untuk adaptasi tanaman terhadap cekaman kekeringan. Pada kondisi cekaman kekeringan maka stomata akan menutup sebagai upaya untuk menahan laju transpirasi.

Penggunaan tanah salin untuk media tanam tanaman sawi akan mengakibatkan kerusakan kloroplas dan adanya ketidak seimbangan unsur hara yang terkandung di dalam tanah. Oleh karena untuk mengurangi cekaman tanah salin tehadap tanaman sawi akan di uji penggunaan bakteri
Synechococcus sp. Bakteri Synechococcus sp. merupakan bakteri fotosintetik untuk mempercepat laju fotosintesis pada tanaman dan dapat meningkatkan kadar nitrogen yang ada pada tanaman sehingga dapat menambat unsur nitrogen dari udara. Bakteri Synechcocus sp dapat mengefisiensikan serapan hara yang berada didaerah perakaran dan juga memperbaiki proses fiksasi N2. Bakteri tersebut juga terkandung suatu hormon auksin. Menurut (Dwijo Saputro, 1978) auksin dapat memperbaiki pertumbuhan daerah perakaran. Peranan auksin antara lain dalam pembelahan dan pembesaran sel serta diferensiasi sel. Sehingga daerah perakaran yang rusak akibat unsur $\mathrm{NaCl}$ yang berlebih dapat berfungsi dengan baik. Bakteri tersebut juga dapat memperbaiki orgenel sel yang rusak akibat kandungan $\mathrm{NaCl}$ yang tinggi sehingga organel sel sehingga dapat membantu proses fotosintesis pada tanaman sawi dan dapat menyeimbangkan unsur hara sehingga unsur hara pada tanaman sawi dapat tercukupi. Oleh karena itu, sangat penting dilakukan penelitian untuk mengetahui pertumbuhan tanaman sawi yang berasosiasi dengan Synechococcus sp pada berbagai kondisi media salinitas.

\section{BAHAN DAN METODE}

Penelitian dilakukan di Desa Bendoarum Kecamatan Wonosari Kabupaten Bondowoso pada bulan November 2016 sampai selesai. Bahan yang digunakan yaitu benih sawi hijau atau caisim, biakan bakteri fotosintetik (Synechococcussp), air, tanah, pasir, garam, dapur $(\mathrm{NaCl})$, pupuk (urea, SP-36 dan $\mathrm{KCl}$ ). Alat yang digunakan untuk penelitian ini yaitu polybag $35 \times 35$, cangkul, handspayer, gembor, klorofilmeter, penggaris, oven, timbangan analitik. Rancangan penrcobaan dalam penelitian ini menggunakan rancangan acak kelompok (RAK) dengan dua kombinasi perlakuan dan terdiri dari 4 ulangan. Faktor pertama adalah inokulasi bakteri fotosintetik terdiri dari dua taraf yaitu B0 (tidak di inokulasi bakteri Synechococcus sp) dan B1 (di inokulasi bakteri Synechococcus sp).Faktor kedua adalah cekaman salinitas yang terdiri dari lima taraf dengan penambahan garam dapur $(\mathrm{NaCl})$ yaitu 0 ppm, 2500 ppm, 5000 ppm, 7500 ppm, 10000 ppm. Masing masing perlakuan diulang sebanyak empat kali.

Parameter yang diamati meliputi jumlah klorofil, jumlah daun, panjang akar, dan volume akar. Analisis dialakukan menggunakan analisis ANOVA dan kemudian dilanjutkan dengan analisis lanjutan Uji Duncant.

\section{HASIL DAN PEMBAHASAN}

\section{Hasil Penelitian}

Dari hasil rekapitulasi nilai F-Hitung menunjukkan bahwa terdapat perbedaan yang sangat nyata pada semua parameter pertumbuhan tanaman sawi yang diberikan perlakuan salinitas dan terdapat perbedaan yang sangat nyata antara sawi yang diberikan biakan Synechococcus sp atau yang tidak diberikan biakan Synechococcus sp pada parameter pertumbuhan berat basah dan berat kering tanaman (tabel 1). 
Tabel 1. Rekapitulasi nilai F-hitung pengaruh Synechococcus sp dan konsentrasi garam $\mathrm{NaCl}$ pada parameter penelitian.

\begin{tabular}{lccc}
\hline \multirow{2}{*}{ Parameter } & \multicolumn{3}{c}{ F-hitung } \\
\cline { 2 - 4 } & Synechococcus sp. & Konsentrasi garam NaCl & Interaksi \\
\hline Jumlah klorofil & $0,609^{\mathrm{ns}}$ & $11,336^{*}$ & $0,329^{\mathrm{ns}}$ \\
Jumlah daun & $0,342 \mathrm{~ns}$ & $11,620^{* *}$ & $0,342^{\mathrm{ns}}$ \\
panjang akar & $6,559^{*}$ & $34,251^{* *}$ & $0,494^{\mathrm{ns}}$ \\
Volume akar & $2,840 \mathrm{~ns}$ & $64,298^{* *}$ & $0,363^{\mathrm{ns}}$ \\
Berat basah & $24,785^{* *}$ & $33,530^{* *}$ & $1,846^{\mathrm{ns}}$ \\
Berat kering & $21,820^{* *}$ & $22,377^{* *}$ & $1,512^{\mathrm{ns}}$
\end{tabular}

Keterangan:* : berbeda nyata pada taraf kepercayaan 5\%

** : berbeda sangat nyata pada taraf kepercayaan $5 \%$

Ns : berbeda tidak nyata

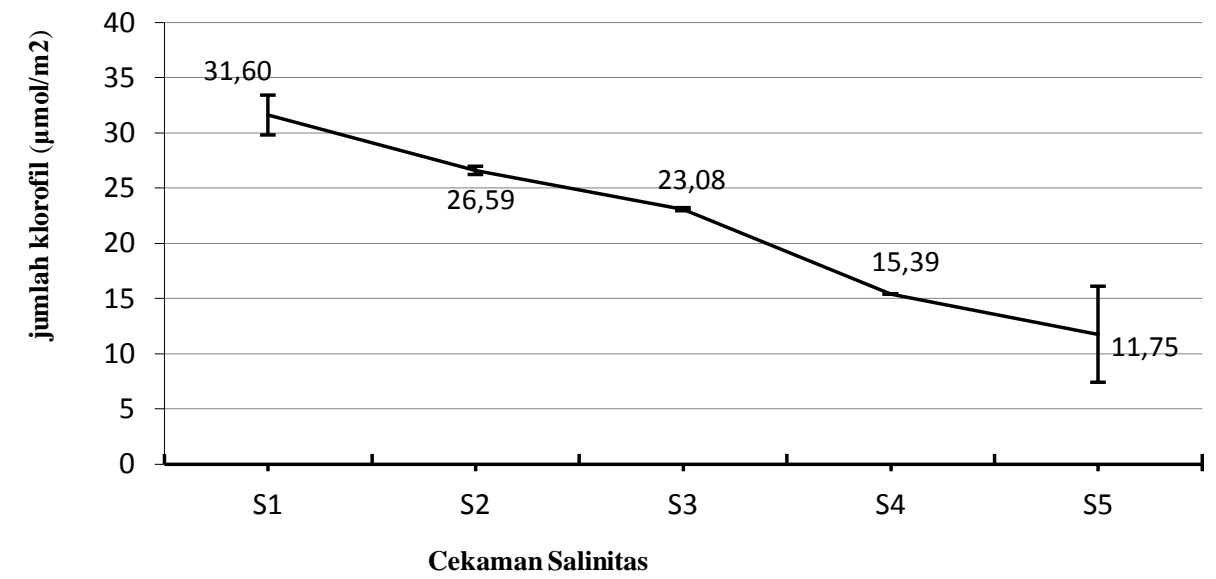

Gambar 1. Pengaruh garam $\mathrm{NaCl}$ terhadap parameter jumlah klorofil tanman sawi.

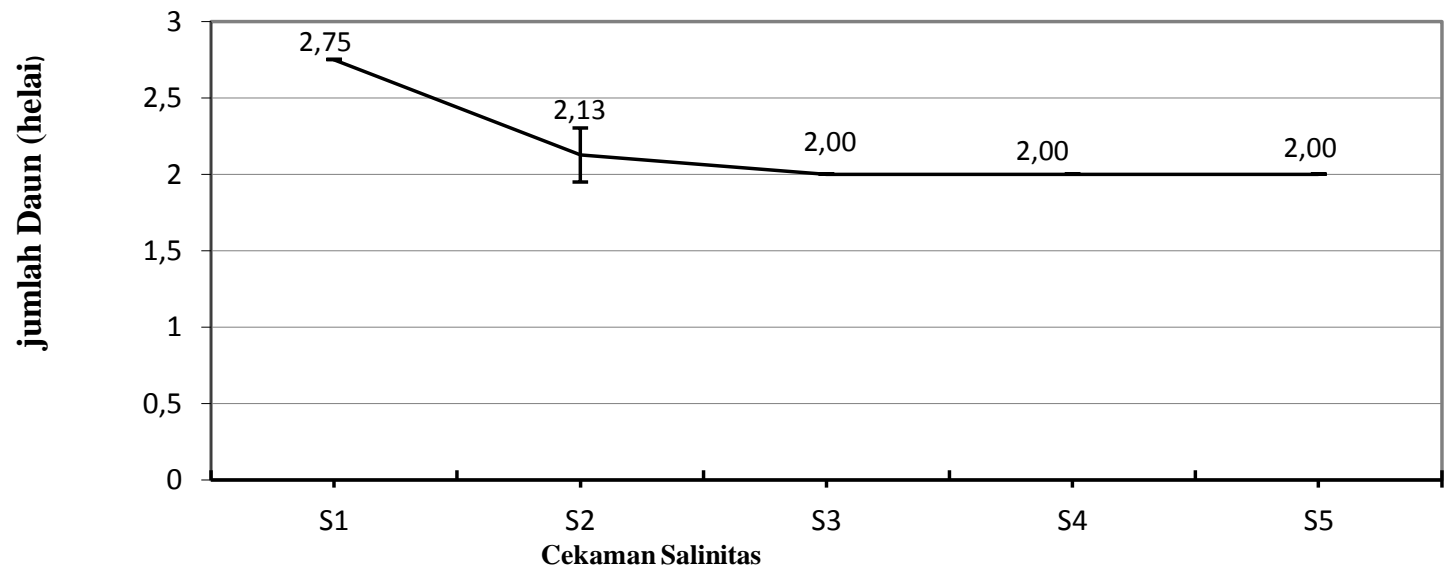

Gambar 2. Pegaruh salinitas pada jumlah daun tanaman sawi hijau 


\section{a. Pengaruh Kandungan Garam NaCl Pada Parameter Pertumbuhan Sawi.}

Dari Hasil uji lanjut Duncan diketahui respon tanaman sawi terhadap kandungan garam $\mathrm{NaCl}$ terdapat beda yang sangat nyata pada semua parameter tanaman diantaranya jumlah klorofil, jumlah daun, panjang akar, volume akar, panjang akar, berat basah, dan berat kering tanaman.

\section{Jumlah klorofil}

Jumlah klorofil pada kosentrasi S5 menunjukkan nilai paling rendah dan berbeda nyata terhadap jumlah klorofil pada konsentrasi S1, S2, S3, dan S4. Jumlah klorofil pada konsentrasi S1 menunjukkan nilai paling tinggi dan berbeda nyata terhadap jumlah klorofil pada konsentrasi S2, S3, S4, dan S5.

\section{Jumlah daun}

Jumlah daun pada konsentrasi S5 menunjukkan nilai paling rendah dan berbeda nyata terhadap jumlah daun pada konsentrasi S1, S2, S3, dan S4. Jumlah daun pada konsentrasi $\mathrm{S} 1$ menunjukkan nilai paling tinggi dan berbeda nyata terhadap jumlah daun pada konsentrasi S2, S3, S4, dan S5.

\section{Panjang akar}

Jumlah daun pada konsentrasi S5 menunjukkan nilai paling rendah dan berbeda nyata terhadap jumlah daun pada konsentrasi S1, S2, S3, dan S4. Jumlah daun pada konsentrasi $\mathrm{S} 1$ menunjukkan nilai paling tinggi dan berbeda nyata terhadap jumlah daun pada konsentrasi S2, S3, S4, dan S5.

\section{Volume akar}

Volume akar pada konsentrasi S5 menunjukkan nilai paling rendah dan berbeda nyata terhadap volume akar pada konsentrasi S1, S2, S3 dan S4. Volume akar pada konsentrasi $\mathrm{S} 1$ mnunjukkan nilai paling tinggi dan berbeda nyata terhadap volume akar pada konsentrasi S2, S3, S4, dan S5.

\section{Berat basah}

Berat basah pada konsentrasi S5 menunjukkan nilai paling rendah dan berbeda nyata terhadap berat basah pada konsentrasi S1, S2, S3, dan S4. Berat basah pada konsentrasi $\mathrm{S} 1$ menunjukkan nilai paling tinggi dan berbeda nyata terhadap berat basah pada konsentrasi S2, S3, S4, dan S5.

\section{Berat kering}

Berat kering pada konsentrasi S4 menunjukkan nilai paling rendah dan berbeda nyata dengan $\mathrm{S} 1, \mathrm{~S} 2$, S3, dan S5. Berat kering pada konsentrasi S1 menunjukkan nilai paling tinggi dan berbeda nyata terhadap berat kering pada konsentrasi S2, S3, S4, dan S5.

b. Pengaruh pemberian Synechococcus sp terhadap beberapa parameter pertumbuhan tanaman sawi

Pada hasil analisa ragam pada tabel 1. Terdapat perbedaan yang nyata pemberian aplikasi Synechococcus sp pada parameter panjang akar, berat basah, dan berat kering tanaman sawi.

\section{Panjang akar}

Panjang akar pada perlakuan BO menunjukkan nilai lebih rendah dan berbeda nyata terhadap panjang akar pada perlakuan B1.

\section{Berat basah}

Berat basah pada perlakuan BO menunjukkan nilai lebih rendah dan berbeda nyata terhadap berat basah pada konsentrasi B1.

\section{Berat kering}

Berat kering pada perlakuan BO menunjukkan nilai lebih rendah dan berbeda nyata terhadap berat kering pada perlakuan B1. 


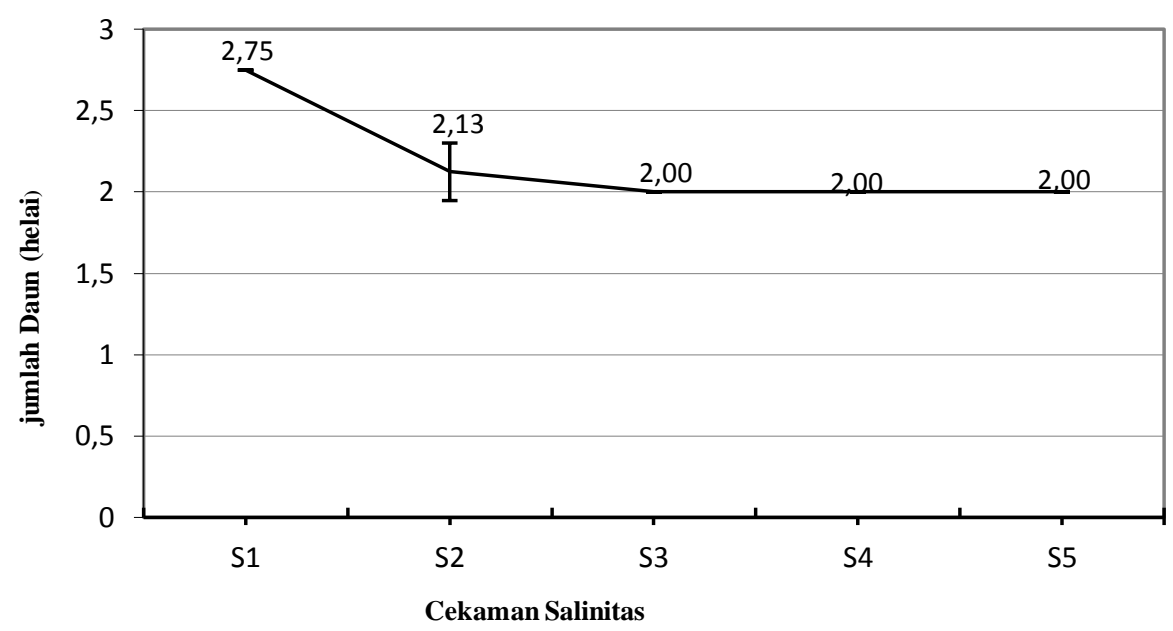

Gambar 3. Pengaruh garam $\mathrm{NaCl}$ pada Panjang akar tanaman sawi

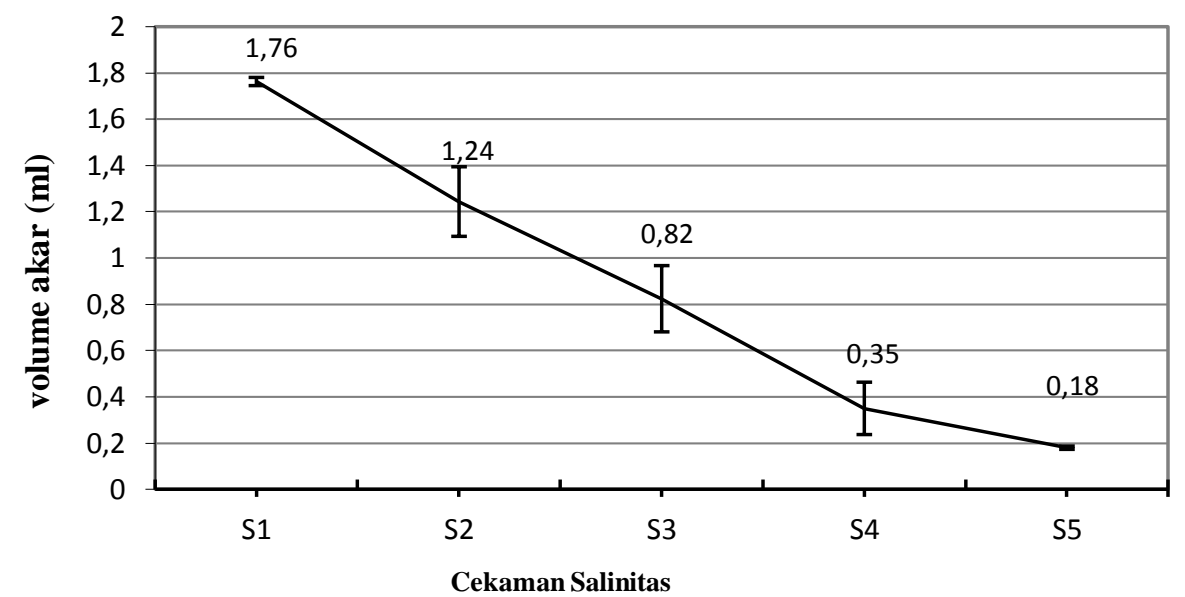

Gambar 4. Pengauh garam $\mathrm{NaCl}$ terhadap Volume akar tanaman sawi.

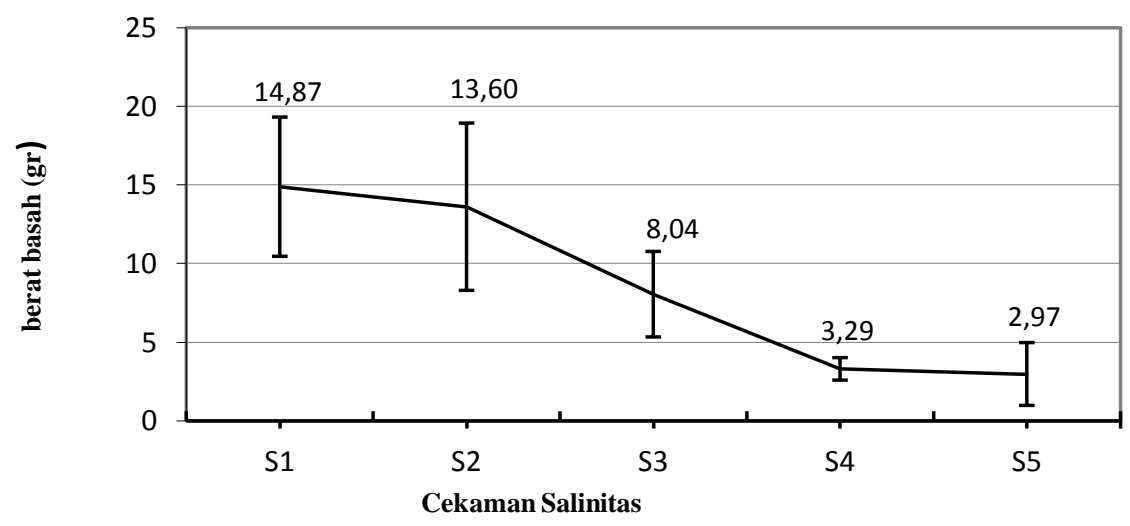

Gambar 5.Pengaruh salinitas pada berat basah tanaman sawi 


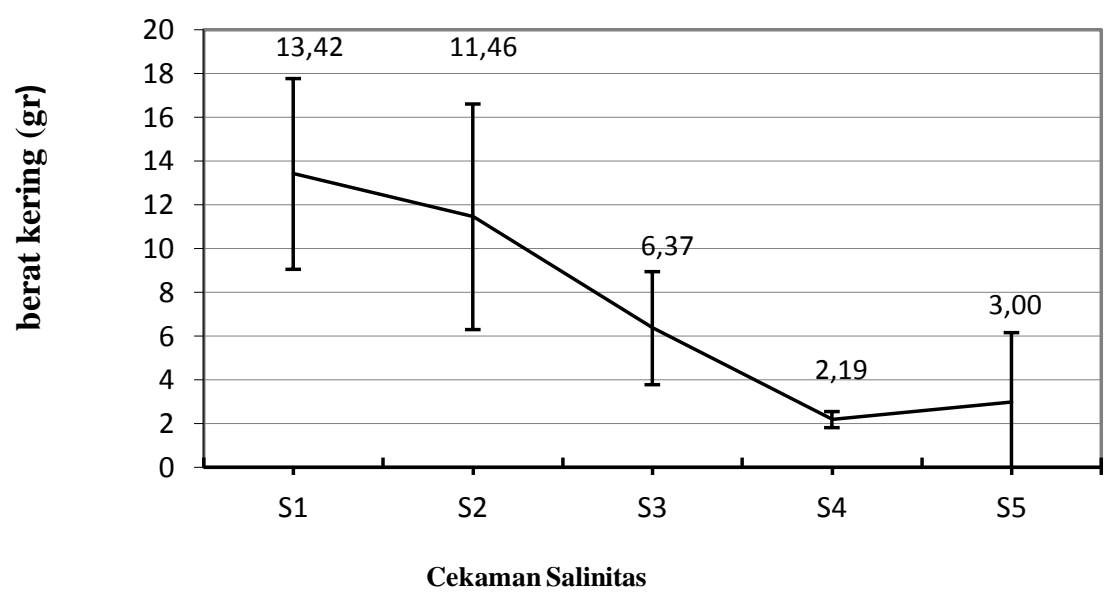

Gambar 6. Pengaruh salinitas terhadap berat kering tanaman sawi

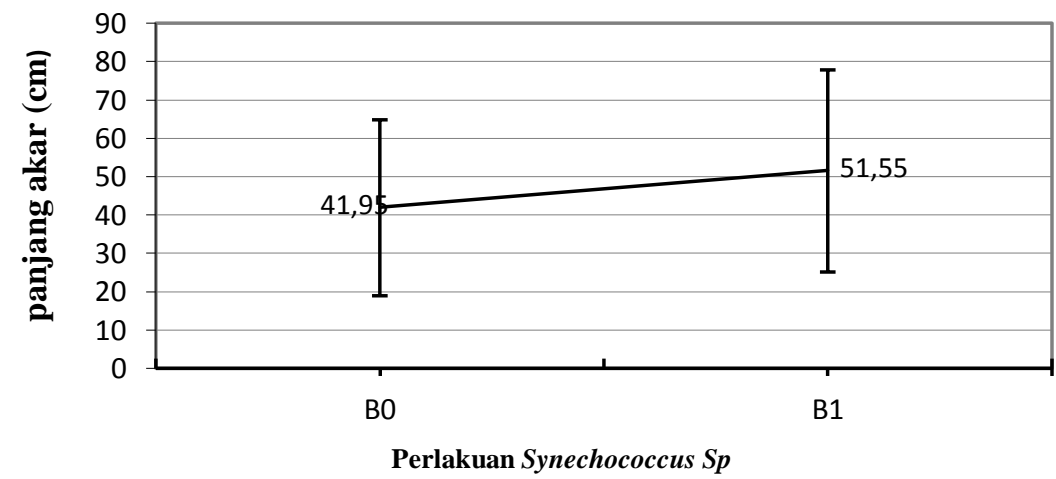

Gambar 7. Pengaruh pemberian Synechococcus sp pada panjang akartanaman sawi

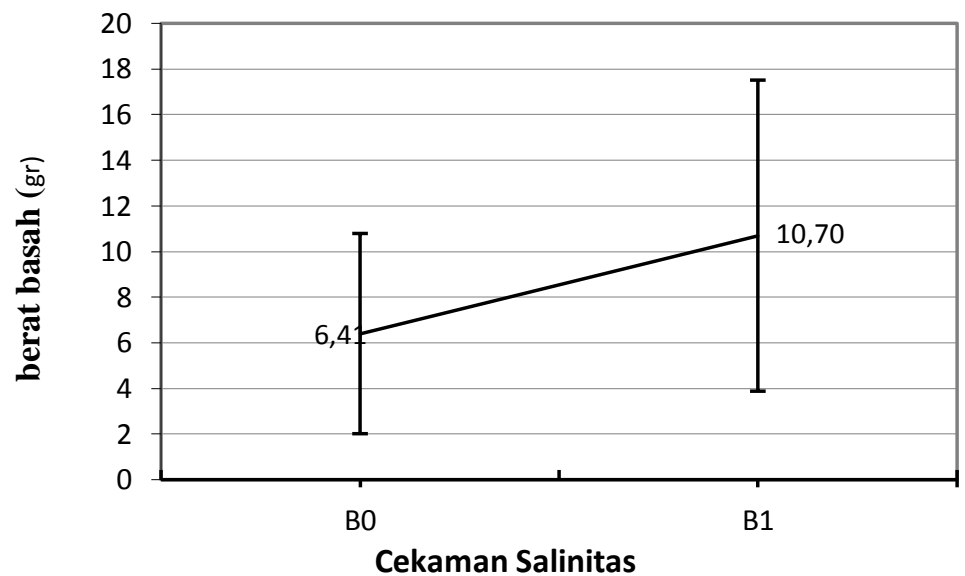

Gambar 8. Pengaruh pemberian Synechococcus sp pada berat basah tanaman sawi 


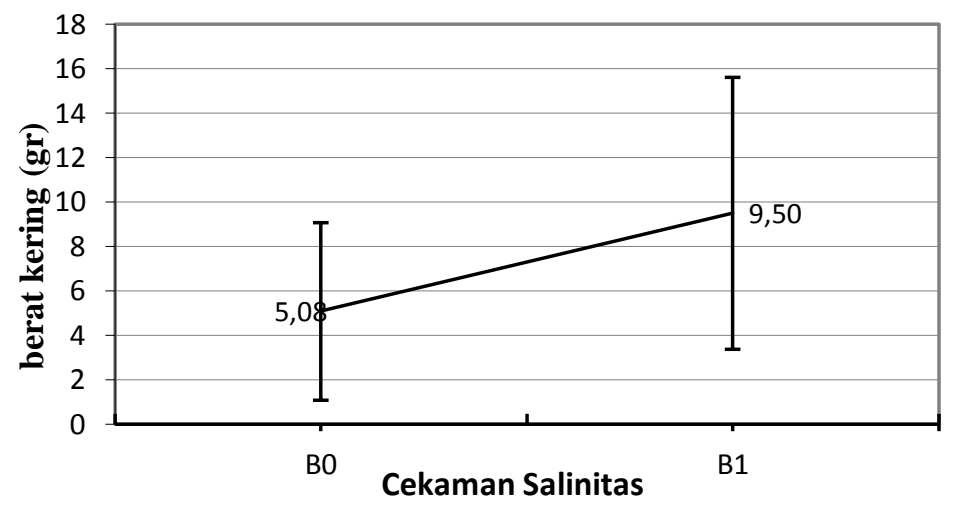

Gambar 9. Pengaruh aplikasi Synechococcus sp pada berat kering tanaman sawi

\section{Pembahasan}

Hasil penelitian menunjukkan bahwa interaksi antara konsentrasi salinitas (S) dan aplikasi Synechococcus $\mathrm{sp}(\mathrm{B})$ tidak terjadi interaksi yang nyata. Hal ini di diduga terjadi karena adanya cekaman yang beragam sehingga pada pemberian aplikasi Synechococcus spyang sudah ditentukan tidak mengakibatkan adanya interaksi yang nyata, walaupun terdapat pengaruh pada pemberian aplikasi Synechococcus sp.Pada pemberian perlakuan konsentrasi 2500 ppm sudah mulai menunjukkan adanya pengaruhnyata dengan kontropada semua nilai parameter pertumbuhan. Hal ini di duga karena pada perlakuan garam $\mathrm{NaCl} 2500$ ppm tanaman sawi hijau mulai mengalami keadaan tercekam sehingga mengurangi pertumbuhannya. Menurut Lopez-perez et al. (2009), cekaman salinitas akan mengubah metabolisme yang lebih diutamakan untuk mengatasi keadaan cekaman yang menyebabkan pertumbuhan mengalami penurunan.

Kandungan konsentrasi garam terlarut dalam tanah akan membuat tekanan osmotik menjadi meningkat, kemampuan tanaman untuk menyerap air akan menurun, dan kemampuan untuk melakukan fotosintesis akan berkurang, sehingga akan berpengaruh terhadap metbolisme tanaman (Follet et al., 198). Selain adanya pengaruh pada metabolismetanaman, kandungan garamdalam tanah yang tinggi dapat menyebabkan adanyaketidakseimbangan antara ion pada penyerapan unsur hara dan kation lain (Brady et Ray, 2008)

Selain itu, adanya kelebihan unsur hara $\mathrm{Na}^{+}$dan $\mathrm{Cl}^{-}$ dapat menurunkan ion lain salah satunya ion $\mathrm{K}^{+}$. Menurut Gardner et al. (1991), adanya kelebihan ion-ion tertentu bersifat antagonis terhadap penyerapan ion-ion lain. Kelebihan ion $\mathrm{Na}^{+}$pada tanaman budidaya dapat menurunkan kandungan ion $\mathrm{K}^{+}$. Ion $\mathrm{K}^{+}$diketahui berfungsi membantu memelihara potensial osmotik dan pengambilan air, serta berperan penting dalam fotosintesis.

Pemberian perlakuan garam $\mathrm{NaCl}$ pada konsentrasi 5000 ppm dan 7500 ppm menunjukkan hasil yang berbeda sangat nyata dengan kontrol. Pemberian perlakuan pada keadaan cekaman yang telah meningkat dan memberikan respon yang berbeda nyata dengan kontrol diduga karena tanaman sawi hijau telah tercekam salinitas dengan konsentrasi yang cukup tinggi. Meningkatnya kandungan $\mathrm{Cl}^{-}$ diikuti pula oleh berkurangnya kandungan NO3- . tanaman yang tercekam salinitas akan menurunkan Chloroplasnya, sehingga proses fotosintesis akan mengalami gangguan (Suwarno, 1985).

Pada konsentrasi 10.000 ppm, pada semua parameter pertumbuhan menunjukkan perbedaan yang sangat nyata dengan kontrol. Hal ini diduga karena karena konsentrasi garam yang sudah sangat tinggi mempengaruhi glucosinolat, sehingga glucosinolat sudah tidak dapat bekerja untuk menurunkan tekanan osmotik yang ada pada tanaman. Menurut $\mathrm{Hu}$ Keling (2010), stres garam $\mathrm{NaCl}$ mempengaruhi kadar isi glucosinolate tanaman dan mengubah komposisi dari glukosinolat alifatik, indol glucosinolate dan aromatik glucosinolate di pakchoi tunas.

Pertumbuhan jumlah daun tanaman awi hijau telah dipengaruhi pada konsentrasi perlakuan garam 2500 ppm 10000 ppm. Keadaan ini disebabkan oleh adanya kandungan garam berlebih yang menghambat dalam proses pembelahan sel. Salah satu akibat dari pengaruh negatif garam di dalam tanah adalah berkurangnya kemampuan tanaman untuk dapat menyerap air dalam tanah sehingga proses pembelahan sel pada tumbuhan akan terganggudan juga mempengaruhi fungsi hormon auksin (Fitter et Hay, 1994).

Tanaman sawi hijau juga terpengaruh oleh cekaman salinitas garam $\mathrm{NaCl}$ pada pertumbuhan panjang akar. Adanya cekaman salinitas yang tinggi diduga menyebabkan berkurangnya pembelahan sel-sel pada akar. Potensi osmotik media tumbuh yang lebih rendah dibandingkan dengan potensial osmotik didalam sel, dapat menghambat pembelahan sel-sel akar (Yuniati, 2004).

Tanaman sawi yang diberikan perlakuan synechococcus sp menunjukkan adanya perbedaan yang nyata dengan tidak diberikannya perlakuan terhadap panjang akar tanaman pada semua konsentrasi salinitas. Hal ini di duga karena adanya faktor lain yang mempengaruhi jumlah akar pada tanaman sawi.

Adanya salinitas tanah juga mulai menunjukkan adanya pengaruh nyata pada berat basah dan berat kering tanaman sawi hijau pada konsentrasi konsentrasi 5000 ppm. Berat basah berkaitan dengan jumlah daun dan panjang akar tanaman. Semakin meningkatnya $\mathrm{Na}+$ dan $\mathrm{Cl}$ - yang diserap 
oleh jaringan akan mengahmbat metabolisme tanaman (Lubis, 2008).

Adanya ion-ion yang tidak seimbang di dalam tanah akan menyebabkan semakin menurunnya kemampuan akar untuk menyerap air dan akan menurunkan jumlah air dalam tanaman sehingga pada parameter berat kering terjadi pengurangan nilai. Penurunan nilai padaa parameter berat kering dipengaruhi oleh penurunan jumlah air pada tanaman sehingga menyebabkan terjadinya penurunan kemampuan fotosintesis, akibatnya karbohidrat sebagai sumber energi untuk pertumbuhan tanaman akan mengalami penurunan ( Gardner et al. 1991 ). Adanya ketidakseimbangan ion pada akar menyebabkan menurunnya $\mathrm{K}+$ karena adanya perlakuan garam dapat mempengaruhi stomata, perlakuan garam $\mathrm{NaCl}$ menyebabkan stomata akan menutup ( Gardner et al. 1991 ). Menutupnya stomata dapat mengurangi adanya asupan $\mathrm{CO} 2$ ke sel-sel mesofil dan menghambat terjadinya fotosintesis (Fitter et Hay, 1994).

Kandungan klorofil pada tanaman sawi mengalami penurunan dengan adanya perlakuan salinitas, keadaan ini diduga karena cekaman salinitas menyebabkan adanya hiperosmotik. Menurut Boudsocq dan Lauriere ( 2005 ) tumbuhan yang tercekam oleh salinitas tinggi akan terdehidrasi dan menyebabkan tumbuhan mengalami tekanan hiperosmotik yang ditandai dengan berkurangnya tekanan turgor dan hilangnya air dari jaringan.

Media tanah yang diukur dalam penelitian ini meliputi $\mathrm{pH}$ dan salinitas. Derajat keasaman atau $\mathrm{pH}$ yang diukur pada awal penelitian adalah 7. Aktivitas enzim dipengaruhi oleh adanya nilai $\mathrm{pH}$. Nilai $\mathrm{pH}$ sesuai dengan tanah yang digunakan pada penelitian ini. Hasil analisis nilai salinitas tanah menunjukkan pada sebelum dan sesudah perlakuan rata-rata menunjukkan peningkatan sebanyak $75 \%$ dari kondisi awal. Peningkatan salinitas di akhir penelitian menunjukkan dengan adanya penyiraman larutan garam $\mathrm{NaCl}$ menyebabkan terjadinya kelebihan garam yang sebagian diserap oleh tanaman dan sebagian terakumulasi lagi pada media tana

\section{KESIMPULAN}

Berdasarkan hasil penelitian dan pembahasan dapat disimpulkan bahwa: (1). Tidak ada interaksi antara perlakuan pemberian Synechococcus spdan konsentrasi $\mathrm{NaCl}$ terhadap pertumbuhan tanaman sawi. (2) Semakin tinggi konsentrasi $\mathrm{NaCl}$ hingga mencapai 10.000 ppm maka parameter pertumbuhan tanaman sawi menunjukkan adanya penurunan atau semakin rendah.

Berdasarkan penelitian ini, peneliti menyarankan adanya penelitian lebih lanjut pada konsentrasi salinitas yang diberikan bakteri Synechococcus $\mathrm{s} p$.

\section{DAFTAR PUSTAKA}

Abrol, I. P. 1986. Salt-Affected Soils: Problems and Prospects in Developing Countries. In: Global Aspects of Food Production. P: 283-305.
Adi, M. I. P. 2009. Kandungan Asam Amino Pada Kedelai yang Berasosiasi dengan Bakteri Synechococcus sp. Skripsi. Jurusan Budidaya Pertanian Fakultas Pertanian Universitas Jember. Jember.

Alihamsyah, T. 2004. Potensi dan Pendayagunaan Lahan Rawa untuk Peningkatan Produktivitas Padi. Ekonomi Padi dan Beras Indonesia. Badan Litbang Pertanian, Jakarta. Hal. 141-151.

Barret-Lennard, EG. 2002. Salth of the earth: time to take it seriosly in: R Ahmad and K.A Malik (Eds). Prospects for Saline Agriculture Kluwer Academic Publisher, Dordrecht Netherlands. 460 p.

Beltagi, M.S. 2008. Exogenous ascorbic acid ( vitamin C) induced anabolic changes for salt tolerance in chick pea ( Cicer arietinum L.).

Brinkman, R and V.P Singh. 1982. Rapid reclamation of brackish water fishponds in acid sulfate soils. ILRI. Publ. Wageningen. Netherlands. P: 318-330.

Boudsocq, M and Lauriere, C. 2005. Osmotic Signaling in Plants: Multiple Patways Mediated by Emerging Kinase Families. Plant Physiology. Vol. 38: 111851194.

Brady, NC, \& Ray, RW, 2008, The Nature And Properties Of Soilfouttenth edition, Upper Suddle River, New Jersey Columbus, Ohio.

Cahyono, B. 2003. Tekhnik dan Strategi Budidaya Sawi Hijau (Pai-Tsai).Yayasan Pustaka Nusantara, Yogyakarta.

Didy Sopandie. 1998. Adaptasi Tanaman terhadapCekaman Hara Mineral. IPB. Bogor.

Dwidjoseputro, D. 1978. Pengantar Fisiologi Tumbuhan. Penerbit PT Gramedia. Jakarta.

Fay, P. 1992. Oxgen relations of nitrogen fixation in Cyanobacteria. Microbiological Riview $56: 340$ 373.

Fitter, AH \& Hay, RKM, 1994, Fisiologi Lingkungan Tanaman, Gadjah Mada University Press, Yogyakarta.

Gardner, PF, Pearce, RB, \& Mitchel, RL, 1991, Fisiologi Tanaman Budidaya, UI Press, Jakarta

Hardjowigeono. S. 1993. Klasifikasi Tanah dan Pedogenesis. Akademika Pressindo, Jakarta.

Haryanto, E., Suhartini, T., Rahayu, E., 2000. 'Sawi dan Selada". Penebar Swadaya, Jakarta.

$\mathrm{Hu}$ Keling I and Zhu Zhujun. 2010. Effects od different concentrations of sodium chloride on plant growth and glucosinolate content and composition in pakchoi. African Jurnal of Biotechnology. 9(28): 4428-4433.

Lopez-Perez, L, Martinez-Ballesta, M.C, Maurel, C, \& Carvajal, M, 2009, 'Changes In Plasma Membrane Composition Of Broccoli Roots As An Adaptation To Increase Water Transport Under Salinity', Journal Phytochemistry, vol. 70, hal. 492-500

Lubis, M. S. 2008. Pertumbuhan dan Kandungan Protein Jagung di bawah Cekaman $\mathrm{NaCl}$. Jurusan Pendidikan Biologi. Yogyakarta. 
McMurry, J. dan R.C. Fay. 2004. McMurry Fay Chemistry $4^{\text {th }}$ edition. Belmont : Pearson Education International.

McKersie, B.D. et al. (1999) Winter survival of transgenic alfalfa overexpressing superoxide dismutase. Plant Physiol. 119, 839-848.

M.S. Swaminathan and S.K Sinha (Eds.) Tycooly International Riverton, New Jersey-United States.

Pradani Dan Evi. 2009. Pemanfaatan Fraksi Cair Isolat Pati Ketela Pohon Sebagai Media Fermentasi Pengganti Air Tajin Pada Pembuatan Sayur Asin. Skripsi. Semarang: Jurusan Tekhnik Kimia Fakultas Tekhnik Universitas Diponegoro.

Prasetyo, R. 2005. Kajian Aplikasi Bakteri Synechococcus sp. dan Dosis Pupuk N, P, K terhadap Hasil Biji Tanaman Kedelai (Glycine max L.) (Karya tulis yang tidak dipublikasikan). Jurusan Budidaya Pertanian Fakultas Pertanian Universitas Jember, Jember.

Poerwodidodo. 2002. Metode Selidik Tanah. Usaha Nasional. Surabaya.

Sairam, R.K Dan A, Tyagi, 2004. Physiology And Moleculer Biology Of Salinity Stress Tolerance Ini Plants. Division Of Plants And Division Of Biochemistry. Indian Agricultural Research Intitute New Delhi India.

Sembiring, H Dan A. Gani. 2005. Adaptasi Varietas Padi Pada Tanah Terkena Tsunami. Diakses Pada Tanggal 6 April 2016.

Slinger, D. and Tenison, K. 2005. Salinity Glove Box Guide-NSW Murray and murrum bidgee Catchments.
An initiative of the Southern Salt Action Team, NSW Departement of Primary Industries.

Soedradjad, R. dan S. Avivi. 2005. Efek Aplikasi Synechococcus $\mathrm{Sp}$ pada daun dan pupuk NPK terhadap parameter Agronomi kedelai. Bulletin Agronomi Vol: XXXIII NO: 3 : 17-23.

Soepardi, G. 1983. Sifat dan Ciri Tanah Jurusan Tanah Fakultas Pertanian Institut Pertanian. Institut Pertanian Bogor. Bogor. Hal 591.

Sunarto. 2001. Toleransi kedelai terhadap salinitas. Bul. Agron. (29) (1) : 27-30.

Suriadikarta, D. A, Dan T. Sutriadi. 2007. Jenis-Jenis Lahan Rawa. Litbang Pertanian. 26 (3). Balai Penelitian Tanah. Jalan Ir. H. Juanda No. 98.Bogor.

Reddy, M.P. \& E.R.R. Ivengar. 1999. Crop Tanggapanes to salt cekaman seawater application and prospects. Dalam M. Pessarakli (Ed.). Handbook of Plant and Crop Stress. Marcel Dekker, Inc. New York.

Suwarno. 1985. Pengaruh Larutan $\mathrm{NaCl}, \mathrm{KCL}$, Dan $\mathrm{K}_{2} \mathrm{SO}_{4}$ Iso Osmotik Terhadap Pertumbuhan Dan Hasil Padi. Jurusan Ilmu Tanaman Program Pascasarjana. IPB. 36 Hal.

Tan, Kim. H. 2000. Enviromental Soil Science $2^{\text {nd }}$ Ed. Marcel Dekker. New York. 452 P.

Yamaguchi T, Bumwald E. (2005). Developing salt-toleran crop plants: challenges and opportunities. Trends Plants Sci. 10: 615-620.

Yuniati, R. 2004. Penapisan Galur Kedelai (Glycine max L) Merrill Toleran terhadap $\mathrm{NaCl}$ untuk penanaman di Lahan Salin. Makara Sains 8:1 April 204: 21-24.. 